\title{
Elevation of Ambient Room Temperature has Differential Effects on MDMA-Induced 5-HT and Dopamine Release in Striatum and Nucleus Accumbens of Rats
}

\author{
Esther O'Shea', Isabel Escobedo', Laura Orio', Veronica Sanchez', Miguel Navarro' ${ }^{2}$ A Richard Green ${ }^{3}$ and \\ M Isabel Colado*,I \\ 'Departamento de Farmacologia, Facultad de Medicina, Universidad Complutense, Madrid, Spain; ${ }^{2}$ Departamento de Psicobiologia, Facultad de \\ Psicologia, Universidad Complutense, Madrid, Spain; ${ }^{3}$ Pharmacology Research Group, School of Pharmacy, De Montfort University, Leicester, UK
}

\begin{abstract}
3,4-Methylenedioxymethamphetamine (MDMA) produces acute dopamine and 5-HT release in rat brain and a hyperthermic response, which is dependent on the ambient room temperature in which the animal is housed. We examined the effect of ambient room temperature $\left(20\right.$ and $30^{\circ} \mathrm{C}$ ) on MDMA-induced dopamine and 5-HT efflux in the striatum and shell of nucleus accumbens (NAc) of freely moving rats by using microdialysis. Locomotor activity and rectal temperature were also evaluated. In the NAc, MDMA (2.5 or $5 \mathrm{mg} / \mathrm{kg}$, i.p.) produced a substantial increase in extracellular dopamine, which was more marked at $30^{\circ} \mathrm{C}$. $5-\mathrm{HT}$ release was also increased by MDMA given at $30^{\circ} \mathrm{C}$. In contrast, MDMA-induced extracellular dopamine and $5-\mathrm{HT}$ increases in the striatum were unaffected by ambient temperature. At $20^{\circ} \mathrm{C}$ room temperature, MDMA did not modify the rectal temperature but at $30^{\circ} \mathrm{C}$ it produced a rapid and sustained hyperthermia. MDMA at $20^{\circ} \mathrm{C}$ room temperature produced a two-fold increase in activity compared with salinetreated controls. The MDMA-induced increase in locomotor activity was more marked at $30^{\circ} \mathrm{C}$ due to a decrease in the activity of the saline-treated controls at this high ambient temperature. These results show that high ambient temperature enhances MDMA-induced locomotor activity and monoamine release in the shell of NAc, a region involved in the incentive motivational properties of drugs of abuse, and suggest that the rewarding effects of MDMA may be more pronounced at high ambient temperature.

Neuropsychopharmacology (2005) 30, I312-1323, advance online publication, 9 February 2005; doi: I 0. I038/sj.npp. I 300673
\end{abstract}

Keywords: MDMA; dopamine; 5-HT; nucleus accumbens; locomotor activity; room and rectal temperature

3,4-Methylenedioxymethamphetamine (MDMA or 'ecstasy') is a commonly used recreational drug, often ingested at crowded and warm dance clubs and raves. The main adverse effect related to acute MDMA toxicity is hyperthermia, with body temperatures as high as $43^{\circ} \mathrm{C}$ having been reported (Henry, 1992). The hyperthermic response is responsible for most of the deaths caused by the drug since many of the other toxicological problems that are seen, particularly rhabdomyolysis, disseminated intravenous coagulation, and acute renal failure (Brown and Osterloh, 1987; Henry et al, 1992; Screaton et al, 1992) result from hyperthermia. Hyperthermia is also observed in experimental animals immediately after drug

*Correspondence: Professor MI Colado, Departamento de Farmacologia, Facultad de Medicina, Universidad Complutense, Madrid 28040, Spain, Tel: + 34 91 394 1213, Fax: + 3491394 1463,

E-mail:colado@med.ucm.es

Received 17 March 2004; revised 3 November 2004; accepted I December 2004

Online publication: 17 December 2004 at http://www.acnp.org/citations/ Npp 12 1704040 123/default.pdf injection and its magnitude is very dependent on ambient room temperature during drug exposure (eg Green et al, 2004).

Systemic MDMA administration has also been shown to increase extracellular dopamine and 5-HT levels in mesolimbic brain areas such as the nucleus accumbens (NAc) (Yamamoto and Spanos, 1988; Marona-Lewicka et al, 1996; Kankaanpaa et al, 1998). The NAc is a brain area that is responsible for the incentive motivational properties of most drugs of abuse and the rewarding effects of MDMA have been shown using the appropriate paradigms. Thus, rats treated with MDMA developed a positive and dosedependent response in the conditioned place preference (CPP) test (Marona-Lewicka et al, 1996; Bilsky et al, 1991; Bilsky and Reid, 1991; Schechter, 1991). Since CPP is believed to be a measure of appetitive behavior where the animal associates contextual cues with either a positive or negative feeling produced by the drug, these results provide direct evidence of the rewarding properties of MDMA in rats. A rewarding effect of MDMA has also been shown in the self-stimulation paradigm in rats (Hubner et al, 1988), 
where MDMA lowers the reward threshold of electrical stimulation, and in the drug self-administration test in rats (Schenk et al, 2003; Daniela et al, 2004) and baboons (Lamb and Griffiths, 1987). The locomotor hyperactivity observed after MDMA injection is also consistent with this drug exerting a positive rewarding effect (Gold and Koob, 1988; Gold et al, 1989a). 6-Hydroxydopamine lesions of the NAc attenuated the locomotor response produced by MDMA (Gold et al, 1989b), and dopaminergic activity thus appears to be selectively responsible for MDMA- and amphetamineinduced locomotor activity, since blockade of dopamine receptors or 6-OHDA lesions of mesolimbic dopamine fibers did not block caffeine, scopolamine, heroin, or corticotrophin-releasing factor-induced locomotor activation (Swerdlow and Koob, 1985; Vaccarino et al, 1986). On the other hand, the fact that 6-OHDA lesions of the NAc attenuated, but did not abolish, the MDMA-induced hyperactivity (Gold et al, 1989b) indicates that the MDMA-induced dopamine release in the NAc is not the sole cause of the rewarding effects of MDMA and there is some evidence that serotoninergic activity may also be involved.

Recently, it was shown that an elevation of ambient room temperature enhanced the prosocial effects of MDMA and the number of MDMA infusions self-administered by rats (Cornish et al, 2003). This suggests that the rewarding effects of MDMA are more pronounced at high ambient temperature and that the enthusiasm of recreational users for consuming the drug in hot environments might not be coincidental. Nevertheless, it is not known whether the neurochemical changes related to the rewarding effects of MDMA are in any way dependent on the ambient room temperature in which the drug is ingested.

Using in vivo microdialysis, we have now examined the effect of ambient temperature on MDMA-induced dopamine and 5-HT output and metabolism in the striatum and in the shell of NAc of freely moving rats. Locomotor activity and body temperature during drug exposure was also evaluated at standard $\left(20^{\circ} \mathrm{C}\right)$ and high $\left(30^{\circ} \mathrm{C}\right)$ room ambient temperature.

\section{MATERIALS AND METHODS}

\section{Animals and Drug Administration}

Male Dark Agouti rats (175-200g, Interfauna, Barcelona) were used. They were housed in groups of five, in conditions of constant temperature $\left(21 \pm 2^{\circ} \mathrm{C}\right)$ and a $12 \mathrm{~h}$ light/dark cycle (lights on: 0700), and given free access to food and water. In order to habituate the animals to the different ambient temperatures studied, on the day of the experiment, rats were maintained at an ambient room temperature between either 19 and $21^{\circ} \mathrm{C}$ (referred to in the text as $20^{\circ} \mathrm{C}$ ) or 30 and $32^{\circ} \mathrm{C}$ (referred to as $30^{\circ} \mathrm{C}$ ) for $2.5 \mathrm{~h}$ before MDMA (2.5 or $5 \mathrm{mg} / \mathrm{kg}$, i.p.) administration and these conditions were maintained for the entire experimental procedure. Rectal temperature data and microdialysate data were obtained from the same animals and separate animals were used for the locomotor activity assessment. Animals were only treated at one dose level and used to study one brain area.
MDMA (NIDA, Research Triangle Park, NC) was dissolved in saline $(0.9 \% \mathrm{NaCl})$ and given in a volume of $1 \mathrm{ml} / \mathrm{kg}$. Dose is reported in terms of the base.

All experimental procedures were performed in accordance with the guidelines of the Animal Welfare Committee of the Complutense University (following DC86/609/EU).

\section{Measurement of Rectal Temperature}

Immediately before and up to $5 \mathrm{~h}$ after MDMA injection, temperature was measured every $30 \mathrm{~min}$ by use of a digital readout thermocouple (Type $\mathrm{K}$ thermometer, Portec, UK) with a resolution of $\pm 0.1^{\circ} \mathrm{C}$ and accuracy of $\pm 0.2^{\circ} \mathrm{C}$ attached to a CAC-005 Rodent Sensor, which was inserted $2.5 \mathrm{~cm}$ into the rectum of the rat, the animal being lightly restrained by holding in the hand. A steady readout was obtained within $10 \mathrm{~s}$ of probe insertion.

\section{Measurement of Locomotor Activity}

Animals were placed at either ambient room temperature $\left(20\right.$ and $\left.30^{\circ} \mathrm{C}\right) 2.5 \mathrm{~h}$ before treatment and this temperature was maintained for the entire experimental procedure. Rats were treated with MDMA $(5 \mathrm{mg} / \mathrm{kg}$, i.p.) or saline and immediately placed in a locomotor activity chamber. No habituation to the chamber was performed. The opaque plastic chamber measured $35 \times 37 \times 44 \mathrm{~cm}(w \times l \times h)$ with eight infrared beams and photocells distributed in two rows along the length of the chamber. The upper row was raised $10.5 \mathrm{~cm}$ from the base of the cage and the lower row $5.5 \mathrm{~cm}$. Spacing between adjacent beams was $7.5 \mathrm{~cm}$. The locomotor activity measurement consisted of the total number of photocell beam breaks (upper and lower beams) recorded in $30 \mathrm{~min}$ analyzed by a personal computer. Counting began 10 min after injection and placement of the animals in the chamber area.

\section{Implantation of Microdialysis Probe in the NAc and Striatum}

The day before the experiment rats were anaesthetised with pentobarbitone (Euta-Lender, $40 \mathrm{mg} / \mathrm{kg}$ ) and secured in a Kopf stereotaxic frame with the tooth bar at $-3.3 \mathrm{~mm}$ below the interaural zero. A guide cannula was implanted in the right side of the brain according to the following coordinates: $+9.4 \mathrm{~mm}$ from the interaural line, $-1.0 \mathrm{~mm}$ mediolateral, and $-5.4 \mathrm{~mm}$ below the skull for the NAc, and $+7.9 \mathrm{~mm}$ from the interaural line, $-2.5 \mathrm{~mm}$ mediolateral, and $-4.0 \mathrm{~mm}$ below the skull for the striatum (König and Klippel, 1963). Cannulae were secured to the skull as described by Baldwin et al (1994). On the day of the experiment, the dialysis probes (membrane length: $2.0 \mathrm{~mm} \times 500 \mu \mathrm{m}$ for the NAc and $4.0 \mathrm{~mm} \times 500 \mu \mathrm{m}$ for the striatum; CMA/12, Sweden) were inserted in the guide cannulae such that the membrane protruded its full length from the end of the probe.

\section{Measurement of Dopamine, 5-HT and Their Metabolites in the Dialysate}

Catechol and indole efflux in the brain in vivo was measured by the method described in detail by Colado et al (1999). 
At $24 \mathrm{~h}$ after implantation, probes were perfused with artificial cerebrospinal fluid (aCSF; $\mathrm{KCl}: 2.5 \mathrm{mM} ; \mathrm{NaCl}$ : $\left.125 \mathrm{mM} ; \mathrm{MgCl}_{2} \cdot 6 \mathrm{H}_{2} \mathrm{O}: 1.18 \mathrm{mM} ; \mathrm{CaCl}_{2} \cdot 2 \mathrm{H}_{2} \mathrm{O}: 1.26 \mathrm{mM}\right)$ at a rate of $1 \mu \mathrm{l} / \mathrm{min}$ and samples collected from the freely moving animals at 30 min intervals in tubes containing $5 \mu \mathrm{l}$ of a solution composed of $\mathrm{HClO}_{4}(0.01 \mathrm{M})$, cysteine $(0.2 \%)$, and sodium metabisulfite $(0.2 \%)$. The first $60 \mathrm{~min}$ sample was discarded and the next three $30 \mathrm{~min}$ baseline samples collected. After injection, samples were collected every $30 \mathrm{~min}$ for $5 \mathrm{~h}$.

Dopamine, 5-HT and the metabolites, 3,4-dihydroxyphenylacetic acid (DOPAC), homovanillic acid (HVA), and 5-hydroxyindole acetic acid (5-HIAA) were measured in the dialysate by HPLC and electrochemical detection. The mobile phase consisted of $\mathrm{KH}_{2} \mathrm{PO}_{4}(0.05 \mathrm{M})$, octanesulfonic acid $(0.4 \mathrm{mM})$, EDTA $(0.1 \mathrm{mM})$, and methanol $(16 \%)$ and was adjusted to $\mathrm{pH} 3$ with phosphoric acid, filtered and degassed. The flow rate was $1 \mathrm{ml} / \mathrm{min}$. The HPLC system consisted of a pump (Waters 510) linked to an automatic sample injector (Loop $200 \mu \mathrm{l}$, Waters 717 plus Autosampler), a stainless-steel reversed-phase column (Spherisorb ODS2, $5 \mu \mathrm{m}, 150 \times 4.6 \mathrm{~mm})$ with a precolumn and a coulometric detector (Coulochem II, Esa, USA). The working electrode potential was set at $400 \mathrm{mV}$ with a gain of $1 \mu \mathrm{A}$ (for dopamine) and $500 \mathrm{nA}$ (for the remaining compounds). The current produced was monitored by using integration software (Unipoint, Gilson).

\section{Measurement of MDMA Concentration in Striatal Tissue}

Brain concentrations of MDMA were determined following a previously described method with minor modifications (Sanchez et al, 2001). The striatal tissue was homogenized in ice-cold sodium carbonate-sodium bicarbonate buffer ( $\mathrm{pH}$ 11.5) using an ultrasonicator. The homogenate was centrifuged at $27000 \mathrm{~g}$ for $20 \mathrm{~min}$ at $4{ }^{\circ} \mathrm{C}$. The supernatant was applied to a $145 \mathrm{mg}$ C8 end-capped SPE light column (International Sorbent Technology, Waters). The column was washed with methanol $(2 \mathrm{ml})$ followed by distilled water $(2 \mathrm{ml})$ before applying the sample $(400 \mu \mathrm{l}$ of supernatant + $350 \mu \mathrm{l}$ of distilled water). The column was washed with water $(2 \mathrm{ml})$ before selective elution of MDMA with methanol $(1 \mathrm{ml})$.

An aliquot $(20 \mu \mathrm{l})$ of the resulting eluate was injected into a Waters HPLC system, which consisted of a pump (Waters 510) linked to a manual sample injector (Loop $20 \mu \mathrm{l}$, Rheodyne), a stainless-steel column (RP 18, $5 \mu \mathrm{m}$, $150 \times 4.6 \mathrm{~mm}$, XTerra) fitted with a precolumn (RP 18, $5 \mu \mathrm{m}, 20 \times 3.9 \mathrm{~mm}$, XTerra), and a UV/visible detector (Waters 2487). The current produced was monitored using an integrator (Waters M745). The mobile phase consisted of $20 \mathrm{mM}$ potassium dihydrogen phosphate (75\%) and acetonitrile (25\%), $\mathrm{pH} 2.5$; the flow rate was set to $0.8 \mathrm{ml} / \mathrm{min}$ and UV absorption was measured at $235 \mathrm{~nm}$.

\section{Statistics}

Data from the locomotor activity experiments were analyzed using one-way ANOVA followed by Tukey's multiple comparison test where significant differences occurred. Data from brain MDMA levels were analyzed by
Student's $t$-test. Statistical analyses of the temperature measurements and dialysis were performed using the statistical computer package BMDP/386 Dynamic (BMDP Statistical Solutions, Cork, Eire). Data were analyzed by analysis of variance (ANOVA) with repeated measures (program 2V) or, where missing values occurred, an unbalanced repeated measure model (program 5V) was used. Both used treatment as the between subjects factor and time as the repeated measure. To evaluate the effect of ambient temperature, the tests used treatment and ambient temperature as between subjects factors and time as the repeated measure. ANOVA was performed on both pretreatment and post-treatment data. Differences were considered significant at $P<0.05$. The results of the statistical comparisons are included in the figure legends.

\section{RESULTS}

\section{Effect of Ambient Temperature on MDMA-Induced Changes in Rectal Temperature}

MDMA (2.5 or $5 \mathrm{mg} / \mathrm{kg}$, i.p.) produced an effect on the rectal temperature of the rats that was dependent on the ambient temperature in which the animals were when it was administered. At an ambient temperature of $20^{\circ} \mathrm{C}$, MDMA produced an initial decrease in the rectal temperature of the animals in the first $30 \mathrm{~min}$ (Figure 1). Rectal temperature then returned to values similar to those found in salinetreated animals by $1 \mathrm{~h}$ and remained so for at least $5 \mathrm{~h}$. However, when administered at an ambient temperature of $30^{\circ} \mathrm{C}$, MDMA produced a rapid and marked increase in the rectal temperature of the animals, attaining a peak value of 0.9 or $1.3^{\circ} \mathrm{C}$ above the saline controls in the first $30-60 \mathrm{~min}$ and remaining elevated above controls for 2.5 or $3.5 \mathrm{~h}$ (for 2.5 or $5 \mathrm{mg} / \mathrm{kg}$, respectively) (Figure 1 ).

\section{Effect of Ambient Temperature on MDMA-Induced Changes in Locomotor Activity}

When MDMA ( $5 \mathrm{mg} / \mathrm{kg}$, i.p. ) was given to rats housed at $20^{\circ} \mathrm{C}$, it doubled the locomotor activity measured in a $30 \mathrm{~min}$ period starting $10 \mathrm{~min}$ after treatment compared with activity measured in saline-injected rats (Figure 2). Animals housed at $30^{\circ} \mathrm{C}$ and treated with saline showed a $40 \%$ reduction in mean activity compared with salinetreated rats at an ambient temperature of $20^{\circ} \mathrm{C}$, although this difference was not significant. MDMA given at high ambient temperature produced a five-fold increase in activity compared with the saline-treated controls at the same ambient temperature; however, their absolute activity was similar to that seen in MDMA-treated rats given the same dose of drug at $20^{\circ} \mathrm{C}$.

\section{Effect of Ambient Temperature on the MDMA-Induced Changes in Monoamine Release and Metabolism in NAc and Striatum}

Dopamine and metabolites in NAc. Administration of MDMA to rats housed at $20^{\circ} \mathrm{C}$ produced a slight increase $(2.5 \mathrm{mg} / \mathrm{kg}$, i.p.; Figure $3 \mathrm{a})$ or a substantial and rapid increase $(5 \mathrm{mg} / \mathrm{kg}$, i.p.; Figure $3 \mathrm{~b})$ of the extracellular concentration of dopamine, peaking $60 \mathrm{~min}$ after injection 

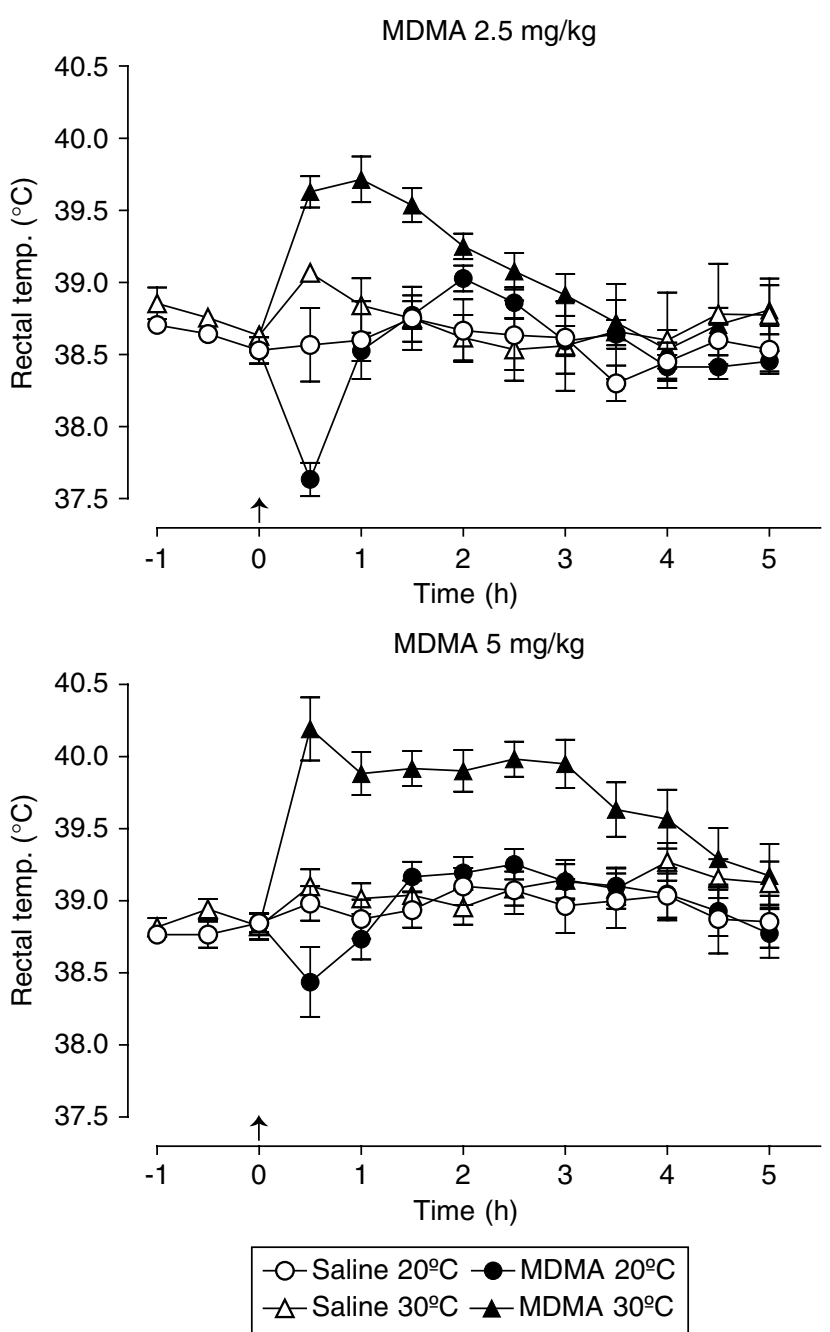

Figure I Rectal temperature of rats injected with MDMA (2.5 or $5 \mathrm{mg} /$ $\mathrm{kg}$, i.p.) at different ambient room temperatures. Animals were maintained at a room temperature of 20 or $30^{\circ} \mathrm{C}$ for $2.5 \mathrm{~h}$ before MDMA injection and for $5 \mathrm{~h}$ after. At $20^{\circ} \mathrm{C}$, MDMA did not significantly modify rectal temperature compared with saline-treated animals (main effect of treatment: $F(I, 19)=0.099$, NS, for $2.5 \mathrm{mg} / \mathrm{kg}$ and $F(I, 24)=0.0024$, NS, for $5 \mathrm{mg} / \mathrm{kg}$ ). Nevertheless, when MDMA was given to animals housed at $30^{\circ} \mathrm{C}$, a pronounced and sustained hyperthermia compared with salinetreated animals was observed (main effect of treatment: $F(I, \mid 8)=3.58$, $P<0.05$, for $2.5 \mathrm{mg} / \mathrm{kg} ; F(1,23)=15.49, P<0.001$, for $5 \mathrm{mg} / \mathrm{kg})$. The interaction of treatment $\times$ ambient temperature was significant at both dosing levels for the interval $0.5-3.5 \mathrm{~h}$ (for $2.5 \mathrm{mg} / \mathrm{kg}$ : $\mathrm{F}(\mathrm{I}, 37)=5.37$, $P<0.05$; for $5 \mathrm{mg} / \mathrm{kg}: F(\mathrm{I}, 47)=13.42, P<0.000 \mathrm{I})$, indicating that the effect of MDMA was different at the two ambient temperatures. Each value is the mean \pm SEM of 8-15 animals.

and lasting $2 \mathrm{~h}$ in the case of the higher dose (Figure $3 \mathrm{~b}$ ). At $30^{\circ} \mathrm{C}$ room temperature, the MDMA-induced increase in the dopamine concentration of the dialysate was greater than that observed at $20^{\circ} \mathrm{C}$ and the enhanced efflux was evident for at least $4.5 \mathrm{~h}$ after drug injection (Figure $3 \mathrm{a}, \mathrm{b}$ ). The content of dopamine in the dialysate of the saline-treated group maintained at $30^{\circ} \mathrm{C}$ was also slightly more pronounced than that found in the saline-treated group maintained to $20^{\circ} \mathrm{C}$ (Figure $3 \mathrm{a}, \mathrm{b}$ ). The absolute basal values of dopamine in the dialysates of saline-treated animals maintained at $30^{\circ} \mathrm{C}$ were similar to those observed in the group at $20^{\circ} \mathrm{C}$ (Table 1 ).

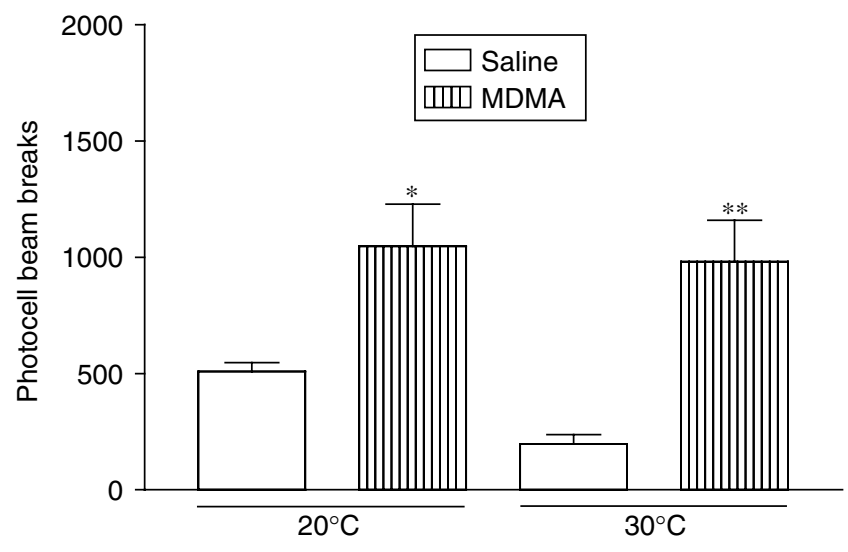

Figure 2 Locomotor activity of rats injected with MDMA ( $5 \mathrm{mg} / \mathrm{kg}$, i.p.) at different ambient temperatures. Animals were maintained at a room ambient temperature of 20 or $30^{\circ} \mathrm{C}$ for $2.5 \mathrm{~h}$ before MDMA injection and during the entire experimental protocol. Rats were placed in the locomotor activity chamber immediately after MDMA injection and the total number of photocell beam breaks was counted for 30 min starting 10 min after placement of animals in the chambers. Each value is the mean \pm SEM of six animals. Different from the corresponding saline-treated group: $* P<0.05, * * P<0.01$.

Injection of MDMA induced a sustained decrease in the levels of DOPAC (Figure 3c, d) and HVA (Figure 3e, f) in the dialysate of animals kept at $20^{\circ} \mathrm{C}$. Similar effects were observed at $30^{\circ} \mathrm{C}$, but the effect on HVA was not significant at the lower MDMA dose (Figure 3e). There was no difference in the levels of DOPAC (Figure 3c, d) and HVA (Figure $3 \mathrm{e}, \mathrm{f}$ ) in the dialysate of saline-treated animals at either ambient temperature. The absolute basal values of DOPAC and HVA in the dialysates of saline-treated animals maintained at $30^{\circ} \mathrm{C}$ were similar to those observed in the group at $20^{\circ} \mathrm{C}$ (Table 1$)$.

5-HT and 5-HIAA in NAc. Administration of MDMA (2.5. or $5 \mathrm{mg} / \mathrm{kg}$, i.p.) to rats at $20^{\circ} \mathrm{C}$ produced a modest increase in the extracellular concentration of 5-HT only at the higher dose that reached a significant difference $v s$ the corresponding saline group between 0.5 and $2.0 \mathrm{~h}$ (Figure $4 \mathrm{a}, \mathrm{b}$ ). However, when MDMA was given at $30^{\circ} \mathrm{C}$, there was an increase in the 5-HT levels in the dialysate peaking $60 \mathrm{~min}$ after injection and lasting for $2-3 \mathrm{~h}$. This effect was significantly different from that observed at $20^{\circ} \mathrm{C}$ (Figure $4 \mathrm{a}, \mathrm{b})$. There was no difference in the levels of 5-HT in the dialysate of saline-treated animals at either temperature (Figure $4 \mathrm{a}, \mathrm{b}$ ). The absolute basal values of $5-\mathrm{HT}$ in the dialysates of saline-treated animals maintained at $30^{\circ} \mathrm{C}$ were similar to those observed in the group at $20^{\circ} \mathrm{C}$ (Table 1).

Injection of MDMA induced a prolonged decrease in 5HIAA levels in the dialysate of animals at $20^{\circ} \mathrm{C}$ (Figure $4 \mathrm{c}$, d). When the animals treated with MDMA $5 \mathrm{mg} / \mathrm{kg}$ were maintained at $30^{\circ} \mathrm{C}$, a biphasic effect was observed, an initial increase in the extracellular 5-HIAA concentration was followed by a sustained and significant decrease. The 5HIAA curves at both room temperatures were significantly different for the interval 0.5-3.5 h (Figure 4d). No such effect was observed at the lower dose (Figure 4c). There was no difference in the levels of 5-HIAA in the dialysate of saline-treated animals kept at either temperature 

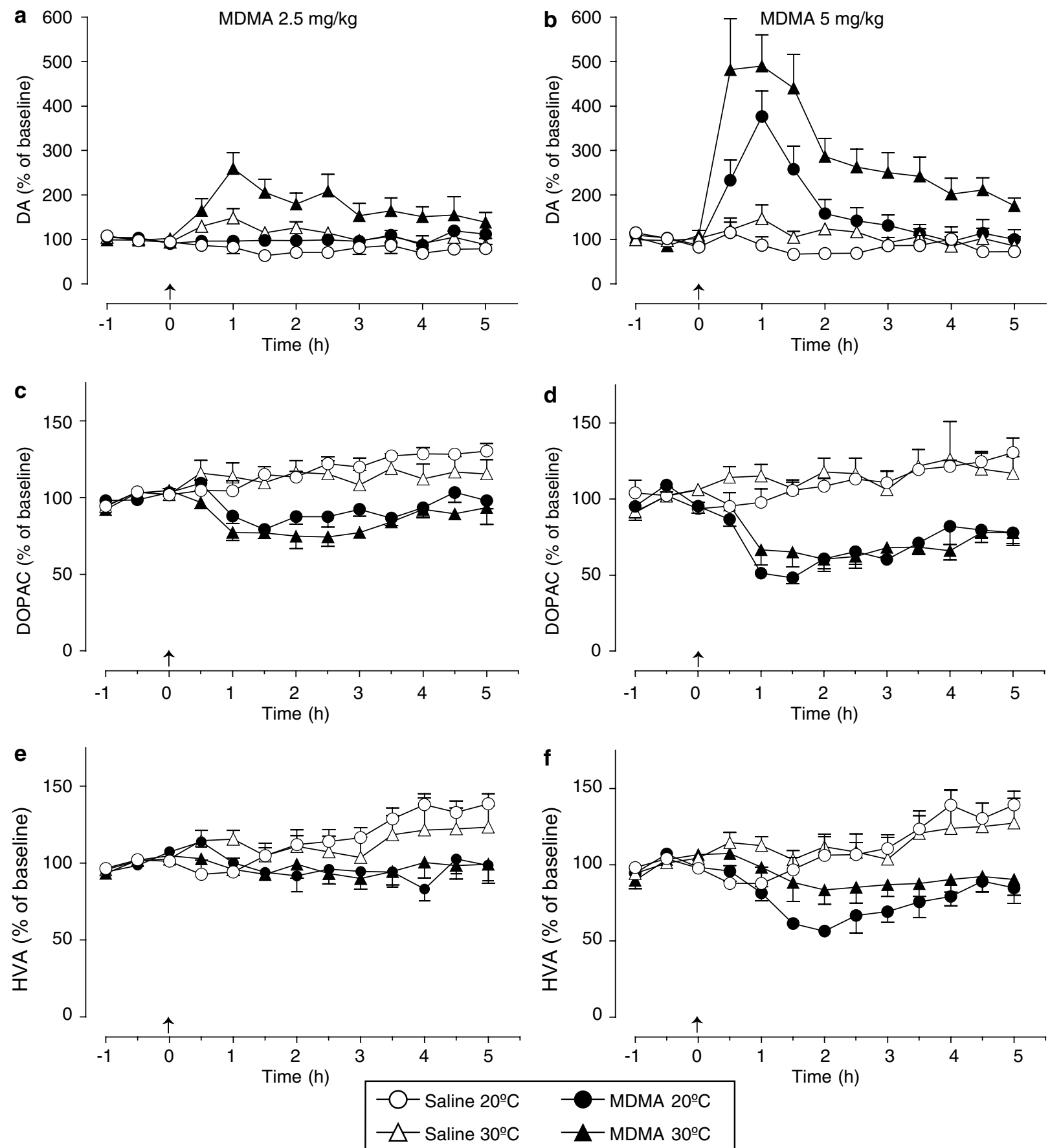

Figure 3 Changes in the extracellular levels of dopamine (DA; a, b), DOPAC (c, d), and HVA (e, $f$ ) in the NAc of rats following administration of MDMA ( 2.5 or $5 \mathrm{mg} / \mathrm{kg}$, i.p.) at different ambient temperatures. Rats were maintained at a room temperature of 20 or $30^{\circ} \mathrm{C}$ for $2.5 \mathrm{~h}$ before MDMA injection and for $5 \mathrm{~h}$ after. At both room temperatures $\left(20\right.$ and $\left.30^{\circ} \mathrm{C}\right)$, MDMA produced an increase in the content of DA compared with saline-treated animals (main effect of treatment: for $2.5 \mathrm{mg} / \mathrm{kg}: \mathrm{F}(\mathrm{I}, \mathrm{I})=5.29, P<0.05 ; \mathrm{F}(\mathrm{I}, \mathrm{I})=8.28, P<0.0 \mathrm{I}$, respectively; for $5 \mathrm{mg} / \mathrm{kg}: \mathrm{F}(\mathrm{I}, \mathrm{I} I)=9.34, P<0.00 \mathrm{I} ; \mathrm{F}(\mathrm{I}, 8)=65.02, P<0.00 \mathrm{I}$, respectively) and a decrease in the levels of HVA (main effect of treatment: for $2.5 \mathrm{mg} / \mathrm{kg}$ at $20^{\circ} \mathrm{C}$ only: $F(I, I 4)=7.93, P<0.01 ;$ for $5 \mathrm{mg} / \mathrm{kg}$ : $F(I, I 0)=17.99, P<0.00 I ; F(I, I 0)=5.45, P<0.05$, respectively), and DOPAC (main effect of treatment: for $2.5 \mathrm{mg}: F(I, I 3)=44.02, P<0.00 I$; $F(I, I 3)=10.76, \quad P<0.00 I$, respectively; for $5 \mathrm{mg} / \mathrm{kg}$ : $F(I, I I)=39.34, \quad P<0.00 I ; \quad F(I, I 0)=26.54, P<0.00 I$, respectively). The interaction of treatment $\times$ ambient temperature was significant for dopamine at both dosing levels (for $2.5 \mathrm{mg} / \mathrm{kg}: F(I, 25)=3.41, P<0.05$ and for $5 \mathrm{mg} / \mathrm{kg}$ : $F(I, 19)=7.63, P<0.01)$ indicating that the effect of MDMA was different at the two ambient temperatures. Animals maintained at $30^{\circ} \mathrm{C}$ and injected with saline showed a modest increase in DA levels compared with those at $20^{\circ} \mathrm{C}$ (main effect of ambient temperature: for (a) $F(I, I 4)=\mid 4.39, P<0.00 I$; for (b) $F(I, 9)=5.26, P<0.05)$. Values are expressed as a percentage of the mean of three measurements before drug administration. Each value is the mean \pm SEM of 5-9 animals. Basal concentrations in saline-treated rats are shown in Table I.

(Figure $4 \mathrm{c}, \mathrm{d}$ ). The absolute basal values of 5 -HIAA in the dialysates of saline-treated animals maintained at $30^{\circ} \mathrm{C}$ were similar to those observed in the group at $20^{\circ} \mathrm{C}$ (Table 1 ).
Dopamine and metabolites in striatum. Administration of MDMA $\left(2.5\right.$ or $5 \mathrm{mg} / \mathrm{kg}$, i.p.) to rats housed at $20^{\circ} \mathrm{C}$ produced a substantial and rapid increase of the extra- 
Table I Basal Values for Extracellular Dopamine (DA), 5-HT, and Corresponding Metabolites in Saline-Treated Rats and Statistical Comparison of the Effect of Temperature

\begin{tabular}{|c|c|c|c|c|c|c|c|c|}
\hline \multirow[b]{2}{*}{ Brain area } & \multirow[b]{2}{*}{ Compound } & \multicolumn{3}{|c|}{$20^{\circ} \mathrm{C}$} & \multicolumn{3}{|c|}{$30^{\circ} \mathrm{C}$} & \multirow[b]{2}{*}{ F-value } \\
\hline & & $-60 \mathrm{~min}$ & $-30 \mathrm{~min}$ & $0 \mathrm{~min}$ & $-60 \mathrm{~min}$ & $-30 \mathrm{~min}$ & $0 \mathrm{~min}$ & \\
\hline \multirow{2}{*}{ NAc } & DOPAC & $204 \pm 23$ & $219 \pm 23$ & $195 \pm 22$ & $165 \pm 20$ & $|82 \pm 2|$ & $188 \pm 20$ & $F(I, 23)=0.90, P=0.35$ \\
\hline & HVA & $112 \pm 12$ & $125 \pm 15$ & $117 \pm 14$ & $102 \pm 11$ & $112 \pm 12$ & $115 \pm 12$ & $F(I, 22)=0.07, P=0.79$ \\
\hline \multirow[t]{4}{*}{ Striatum } & DA & $0.63 \pm 0.07$ & $0.63 \pm 0.08$ & $0.70 \pm 0.09$ & $0.54 \pm 0.06$ & $0.46 \pm 0.05$ & $0.47 \pm 0.05$ & $F(I, 2 I)=3.21, P=0.09$ \\
\hline & DOPAC & $338 \pm 44$ & $399 \pm 55$ & $435 \pm 63$ & $279 \pm 38$ & $361 \pm 49$ & $440 \pm 58$ & $F(I, 23)=0.07, P=0.79$ \\
\hline & HVA & $296 \pm 38$ & $339 \pm 41$ & $375 \pm 48$ & $254 \pm 33$ & $313 \pm 39$ & $390 \pm 49$ & $F(I, 22)=0.01, P=0.92$ \\
\hline & $5-\mathrm{HT}$ & $0.65 \pm 0.08$ & $0.64 \pm 0.08$ & $0.61 \pm 0.07$ & $1.00 \pm 0.15$ & $0.90 \pm 0.11$ & $0.76 \pm 0.12$ & $F(I, 22)=3.54, P=0.07$ \\
\hline
\end{tabular}

Three 30 min baseline samples were collected immediately before injecting MDMA. Values are mean (pg/ $\mu$ l) \pm SEM of 22-25 animals.

cellular concentration of striatal dopamine, peaking at $60 \mathrm{~min}$ and lasting $3-4 \mathrm{~h}$. At $30^{\circ} \mathrm{C}$, the changes induced by MDMA on the dialysate dopamine concentration were similar in magnitude and duration to those observed at $20^{\circ} \mathrm{C}$ (Figure 5a, b). There was no difference in the extracellular concentration of dopamine of saline-treated animals kept at either temperature (Figure $5 \mathrm{a}, \mathrm{b}$ ). The absolute basal values of dopamine in the dialysates of saline-treated animals maintained at $30^{\circ} \mathrm{C}$ were similar to those observed in the group at $20^{\circ} \mathrm{C}$ (Table 1).

Injection of MDMA induced a sustained decrease in the levels of DOPAC (Figure 5c, d) and HVA (Figure 5e, f) in the striatal dialysate of animals kept at either ambient temperature. There was no difference in the levels of DOPAC (Figure $5 \mathrm{c}, \mathrm{d}$ ) or HVA (Figure $5 \mathrm{e}, \mathrm{f}$ ) in the dialysate of saline-treated animals at either temperature. The absolute basal values of DOPAC and HVA in the dialysates of salinetreated animals maintained at $30^{\circ} \mathrm{C}$ were similar to those observed in the group at $20^{\circ} \mathrm{C}$ (Table 1 ).

5-HT and 5-HIAA in striatum. Administration of MDMA ( 2.5 or $5 \mathrm{mg} / \mathrm{kg}$, i.p.) to animals housed at $20^{\circ} \mathrm{C}$ produced a substantial and rapid increase in the extracellular concentration of 5-HT in the striatum peaking $60 \mathrm{~min}$ after injection and lasting 2-3 h (Figure 6a, b). Similar changes were seen in animals housed at $30^{\circ} \mathrm{C}$ (Figure $6 \mathrm{a}, \mathrm{b}$ ). There was no difference in the levels of 5-HT in the dialysate of saline-treated animals at either temperature (Figure 6a, b). The absolute basal values of 5-HT in the dialysates of salinetreated animals maintained at $30^{\circ} \mathrm{C}$ were similar to those observed in the group at $20^{\circ} \mathrm{C}$ (Table 1).

Low-dose MDMA (2.5 mg/kg, i.p.) produced a sustained decrease in the extracellular levels of 5-HIAA, which was not modified by an increase in ambient temperature (Figure 6c). While injection of MDMA at the higher dose to animals at $20^{\circ} \mathrm{C}$ also induced a sustained decrease in dialysate 5-HIAA levels, in animals kept at $30^{\circ} \mathrm{C}$, it induced a biphasic response consisting of an initial rise followed by a decrease (Figure 6d). Nevertheless, 5-HIAA curves at both room temperatures were not significantly different (Figure 6d). There was no difference in the levels of 5HIAA in the dialysate of saline-treated animals kept at different temperatures (Figure $6 c, d$ ). The absolute basal values of 5-HIAA in the dialysates of saline-treated animals maintained at $30^{\circ} \mathrm{C}$ were similar to those observed in the group at $20^{\circ} \mathrm{C}$ (Table 1$)$.

\section{Effect of Ambient Temperature on Striatal Levels of MDMA}

In order to investigate the possible effect of ambient temperature on the concentration of MDMA in the brain, rats were given MDMA $(5 \mathrm{mg} / \mathrm{kg}$, i.p.) and killed $1 \mathrm{~h}$ later. This time point was chosen because the cerebral concentration of MDMA normally peaks $60 \mathrm{~min}$ after MDMA injection (Esteban et al, 2001) and it was the time point at which neurotransmitter release peaked. There were no differences between the MDMA levels found in the striatum of rats treated with the drug at $20^{\circ} \mathrm{C}(22.9 \pm 3.4 \mathrm{nmol} / \mathrm{g}$ tissue, $n=4)$ and those treated at $30^{\circ} \mathrm{C}(22.6 \pm 0.2 \mathrm{nmol} / \mathrm{g}$ tissue, $n=4)$.

\section{DISCUSSION}

Using intracerebral microdialysis in freely moving rats, this study has shown that elevation of ambient temperature enhances the effect induced by low and medium doses of MDMA on dopamine release in the shell of the NAc but not in the striatum. The output of 5-HT is also enhanced in the NAc, but not striatum, by high ambient temperature conditions.

Although MDMA increased both dopamine and 5-HT release in the NAc of animals at $30^{\circ} \mathrm{C}$, the magnitude of the MDMA effect on extracellular dopamine levels (260 and 

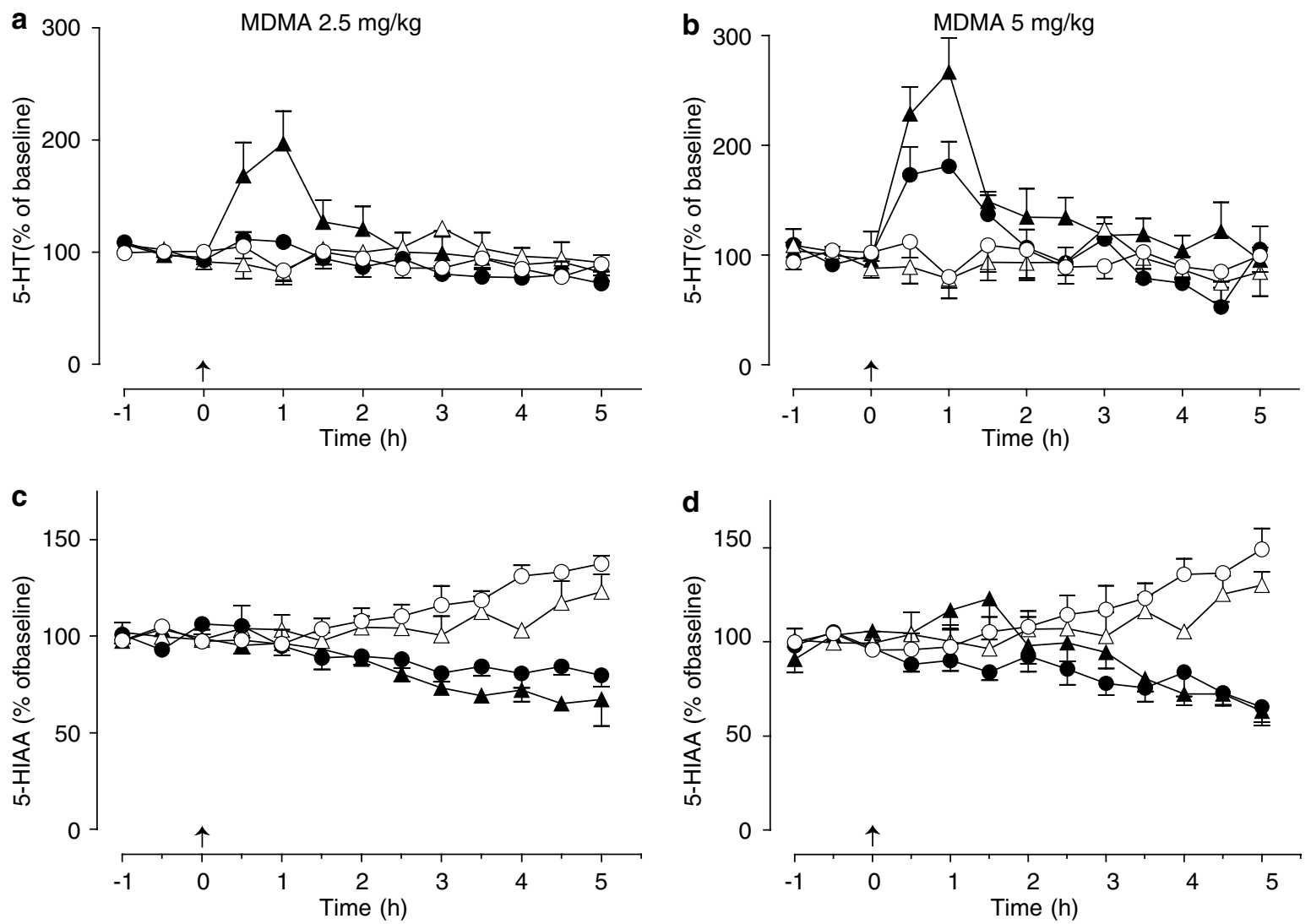

$$
\begin{aligned}
& -\mathrm{O}-\text { Saline } 20^{\circ} \mathrm{C} \\
& -\triangle \text { Saline } 30^{\circ} \mathrm{C}
\end{aligned}
$$

Figure 4 Changes in the extracellular levels of 5-HT (a, b) and 5-HIAA (c, d) in the NAc of rats following administration of MDMA (2.5 or $5 \mathrm{mg} / \mathrm{kg}$, i.p.) at different ambient temperatures. Rats were maintained at a room temperature of 20 or $30^{\circ} \mathrm{C}$ for $2.5 \mathrm{~h}$ before MDMA injection and for $5 \mathrm{~h}$ after. At $20^{\circ} \mathrm{C}$ MDMA (5 mg/ $/ \mathrm{kg}$, i.p.) reduced 5-HIAA levels compared with saline-treated animals (main effect of treatment: $F(I, I 2)=21.21, P<0.00 I)$ and produced a significant increase in 5-HT concentration vs the corresponding saline from 0.5-2.0 h (main effect of treatment: $F(I, 9)=3.97, P<0.05$ ). At 2.5 mg/kg, MDMA only reduced 5-HIAA levels (main effect of treatment: $\mathrm{F}(\mathrm{I}, \mathrm{II})=30.58, P<0.00 \mathrm{I}$ ). When MDMA was given at $30^{\circ} \mathrm{C}$, it produced a pronounced and prolonged increase in 5-HT concentration compared with saline-treated controls (main effect of treatment: for $2.5 \mathrm{mg} / \mathrm{kg}$ between 0.5 and $2.0 \mathrm{~h}$ : $F(I, I 3)=5.86, P<0.0 I$; for $5 \mathrm{mg} / \mathrm{kg}$ between 0.5 and $5 \mathrm{~h}: \mathrm{F}(\mathrm{I}, 9)=18.49, P<0.00 \mathrm{I}$ ). The interaction of treatment $\times$ ambient temperature was significant for $5-\mathrm{HT}$ at both dosing levels (for $2.5 \mathrm{mg} / \mathrm{kg}$ between 0.5 and $2.0 \mathrm{~h}: \mathrm{F}(\mathrm{I}, 26)=4.08, P<0.05$; for $5 \mathrm{mg} / \mathrm{kg}$ between 0.5 and $5 \mathrm{~h}: \mathrm{F}(\mathrm{I}, \mathrm{I} / 8)=4.24, P<0.05$ ), indicating that the effect of MDMA was different at the two ambient temperatures. MDMA also produced a reduction in 5-HIAA levels (main effect of treatment: for $2.5 \mathrm{mg} / \mathrm{kg}$ : $F(I, 8)=8.5 \mathrm{I}, P<0.0 \mathrm{I}$; for $5 \mathrm{mg} / \mathrm{kg}$ : $F(I, 8)=6.06, P<0.0 \mathrm{I})$. The interaction of treatment $\times$ ambient temperature was not significant for $5-\mathrm{HIAA}$ at either dosing level (for $2.5 \mathrm{mg} / \mathrm{kg}: \mathrm{F}(\mathrm{I}, \mathrm{I})=0.00, \mathrm{NS}$; for $5 \mathrm{mg} / \mathrm{kg}$ : $F(\mathrm{I}, 20)=2.27$, NS), indicating that the effect of MDMA was the same at the two ambient temperatures, excepting for the interval $0.5-3.5 \mathrm{~h}$ at the higher dose $(F(1,20)=3.80, P<0.05)$. Values are expressed as a percentage of the mean of three measurements before drug administration. Each value is the mean \pm SEM of 5-8 animals. Basal concentrations in salinetreated rats are shown in Table I.

$490 \%$ increase for 2.5 and $5 \mathrm{mg} / \mathrm{kg}$ at $20^{\circ} \mathrm{C}$ ) was larger than that elicited on 5 -HT concentration (197 and 265\%). This more pronounced effect of MDMA on dopamine release is not a consequence of the high ambient temperature since White et al (1994) observed a similar difference at standard room temperature. Nor can the difference in increases in the levels of DA and 5-HT in the NAc following MDMA be attributed to a different affinity of MDMA for monoamine transporters or to its different potency for inducing $\left[{ }^{3} \mathrm{H}\right]$ DA or $\left[{ }^{3} \mathrm{H}\right]-5-\mathrm{HT}$ release in vitro. Using hippocampal and striatal synaptosomal preparations, it has been shown that MDMA is only slightly more potent at inhibiting $\left[{ }^{3} \mathrm{H}\right]-5-\mathrm{HT}$ than $\left[{ }^{3} \mathrm{H}\right]$-dopamine uptake (1.7 and 3.2 times, in each area, respectively) and that it is 10 times more potent at increasing $\left[{ }^{3} \mathrm{H}\right]-5-\mathrm{HT}$ than $\left[{ }^{3} \mathrm{H}\right]$-dopamine release (Crespi et al, 1997). Nevertheless, in NAc, there is a greater density of dopamine than 5-HT terminals and this morphologic difference may account for the relatively larger MDMAinduced increase in extracellular dopamine levels compared with 5-HT (Dewar et al, 1991; Mennicken et al, 1992). In addition, although 5-HT axon density is higher in the shell of NAc than in the dorsal striatum (Deutch and Cameron, 1992) few axons in the area express 5-HT transporters. It is worth mentioning that MDMA penetrates into 5-HT nerve terminals by means of 5-HT uptake system (Sanchez et al, 2004) and increases 5-HT release through the 5-HT transporter operating in reverse (Rudnick and Wall, 1992).

In addition to increasing dopamine release, MDMA also decreased the extracellular concentrations of DOPAC, HVA, and 5-HIAA in the NAc at both ambient temperatures. This 

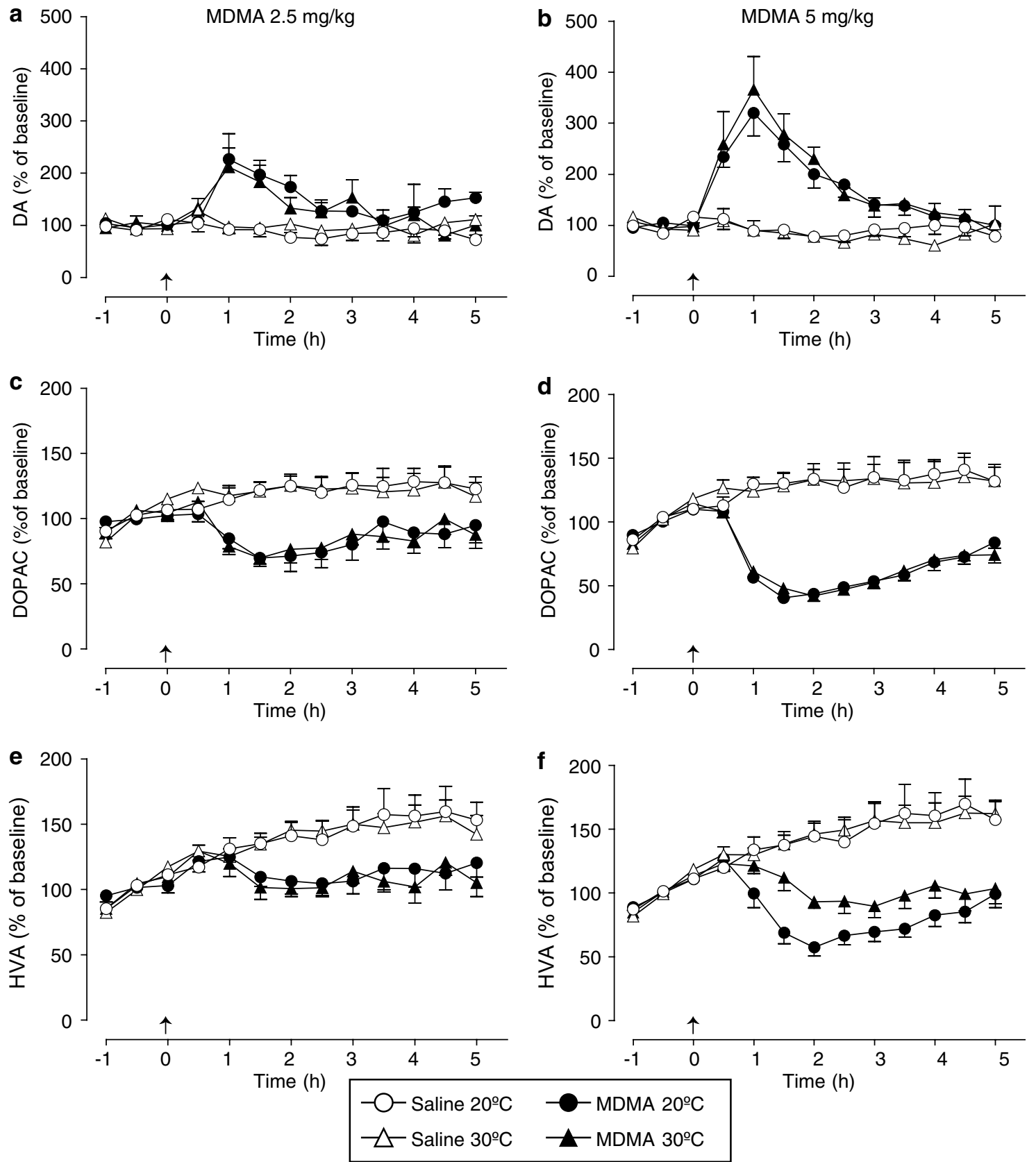

Figure 5 Changes in the extracellular levels of dopamine (DA; a, b), DOPAC (c, d) and HVA (e, f) in the striatum of rats following administration of MDMA (2.5 or $5 \mathrm{mg} / \mathrm{kg}$, i.p.) at different ambient temperatures. Rats were maintained at a room temperature of 20 or $30^{\circ} \mathrm{C}$ for $2.5 \mathrm{~h}$ before $\mathrm{MDMA}$ injection and for $5 \mathrm{~h}$ after. At both room temperatures $\left(20\right.$ and $\left.30^{\circ} \mathrm{C}\right)$, MDMA produced an increase in the content of DA compared with saline-treated animals (main effect of treatment: for $2.5 \mathrm{mg} / \mathrm{kg}: F(I, I I)=\mid 4.6 I, P<0.00 \mathrm{I} ; \mathrm{F}(\mathrm{I}, \mathrm{I} I)=3.5 \mathrm{I}, P<0.05$, respectively; for $5 \mathrm{mg} / \mathrm{kg}: \mathrm{F}(\mathrm{I}, \mathrm{I} \mathrm{I})=22.53, P<0.00 \mathrm{I}$; $F(I, 8)=12.74, P<0.00 \mathrm{I}$, respectively) and a decrease in the levels of HVA (main effect of treatment: for $2.5 \mathrm{mg} / \mathrm{kg}: F(\mathrm{I}, 14)=6.79, P<0.0 \mathrm{I}$; $F(I, I 4)=17.85, P<0.00 \mathrm{I}$, respectively; for $5 \mathrm{mg} / \mathrm{kg}$ : $F(I, I I)=26.6 \mathrm{I}, P<0.00 \mathrm{I} ; F(I, 9)=23.12, P<0.00 \mathrm{I}$, respectively) and DOPAC (main effect of treatment: for $2.5 \mathrm{mg} / \mathrm{kg}$ : $F(I, I 4)=19.26, P<0.001 ; F(I, I 5)=12.01, P<0.00 I$, respectively; for $5 \mathrm{mg} / \mathrm{kg}: F(I, I I)=8 I .67, P<0.00 I ; F(I, I 0)=45.63$, $P<0.00$ I respectively). Values are expressed as a percentage of the mean of three measurements before drug administration. Each value is the mean \pm SEM of 4-9 animals. Basal concentrations in saline-treated rats are shown in Table I.

result could reflect a decrease in the metabolism of the monoamines as a consequence of the ability of MDMA to inhibit MAO activity. The MDMA-induced reduction in 5HIAA levels at the dose of $5 \mathrm{mg} / \mathrm{kg}$ was less pronounced when MDMA was given to rats kept at $30^{\circ} \mathrm{C}$. A reduction in extracellular 5-HT metabolism due to an increased MAO inhibition could be responsible for this effect, but it seems more likely that the high levels of 5-HIAA are reflecting a higher 5-HT release into the extracellular space.

One further possibility that could explain the changes induced by MDMA at high ambient temperature on monoamine release and metabolism in the NAc is enhanced penetration of MDMA through the blood-brain barrier. However, alterations in the pharmacokinetic properties of 

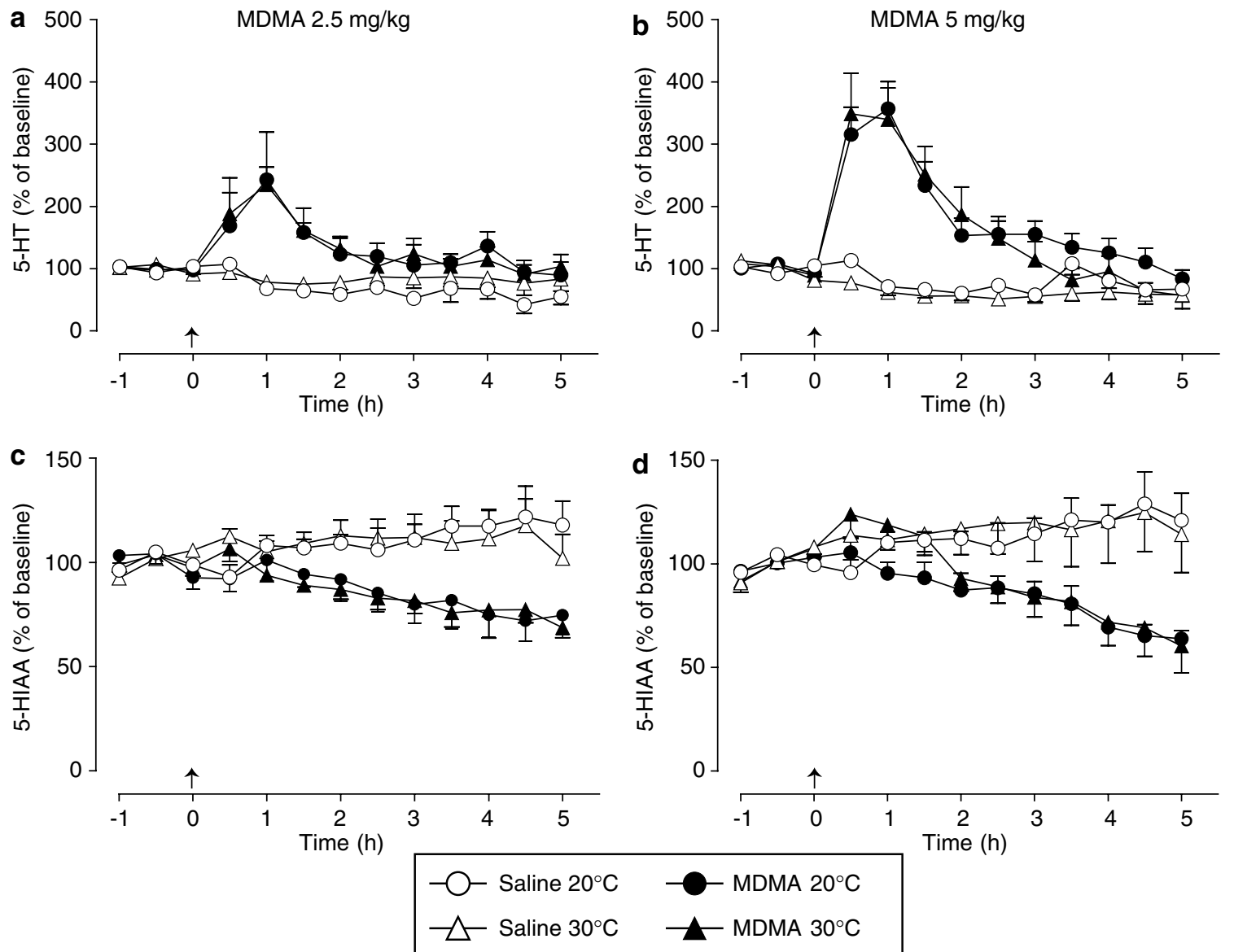

Figure 6 Changes in the extracellular levels of 5-HT $(a, b)$ and 5-HIAA (c, d) in the striatum of rats following administration of MDMA (2.5 or 5 mg/kg, i.p.) at different ambient temperatures. Rats were maintained at a room temperature of 20 or $30^{\circ} \mathrm{C}$ for $2.5 \mathrm{~h}$ before MDMA injection and for $5 \mathrm{~h}$ after. At both room temperatures $\left(20\right.$ and $30^{\circ} \mathrm{C}$ ), MDMA produced an increase in the content of 5-HT compared with saline-treated animals (main effect of treatment: for $2.5 \mathrm{mg} / \mathrm{kg}$ : $F(I, I I)=4.19, P<0.05 ; F(I, I 4)=9.35, P<0.0 I$, respectively; for $5 \mathrm{mg} / \mathrm{kg}: F(I, I I)=I 0.95, P<0.00 I ; F(I, 9)=\mid 0.46, P<0.00 I$, respectively) and a decrease in the levels of 5 -HIAA (main effect of treatment: for $2.5 \mathrm{mg} / \mathrm{kg}$ : $F(I, \mid 4)=7.50, P<0.01 ; F(I, \mid 4)=7.77, P<0.01$, respectively: for $5 \mathrm{mg} / \mathrm{kg}: \mathrm{F}(\mathrm{I}, \mathrm{I})=18.97, \mathrm{P}<0.00 \mathrm{I} ; \mathrm{F}(\mathrm{I}, 8)=3.37, P<0.05$, respectively). The effects of MDMA on 5 -HT and 5-HIAA levels were similar at both ambient temperatures. Values are expressed as a percentage of the mean of three measurements before drug administration. Each value is the mean $\pm \mathrm{SEM}$ of 4-9 animals. Basal concentrations in saline-treated rats are shown in Table I.

the drug at elevated temperature can be discarded since MDMA concentrations in the brain of rats at $30^{\circ} \mathrm{C}$ were similar to those obtained at $20^{\circ} \mathrm{C}$ room temperature.

Administration of MDMA ( 2.5 or $5 \mathrm{mg} / \mathrm{kg}$ ) had little effect on rectal temperature, other than a transient hypothermia, when the drug was given to rats housed at $20^{\circ} \mathrm{C}$, but it produced a sustained and marked hyperthermia when administered to rats housed at $30^{\circ} \mathrm{C}$, confirming previous observations (Green et al, 2004). We have previously shown that the initial hyperthermia that follows MDMA injection appears to be due to dopamine release acting on $D_{1}$ receptors and inhibition of normal heat loss mechanisms that are normally occurring, such as tail vasodilation (Mechan et al, 2002). Since heat loss through this mechanism is presumably more difficult to achieve when the animal is in a high ambient temperature, a clear hyperthermia will occur and is unlikely to be due to greater dopamine efflux and function, rather being due to the environmental conditions. However, we and others, have also found that increased 5-HT function is necessary to enhance heat loss mechanisms when animals are in high ambient temperature conditions. Decreasing cerebral 5-HT content by administration of the tryptophan hydroxylase inhibitor $p$-chlorophenylalanine or a neurotoxic dose of MDMA or administration of the 5-HT antagonist methysergide results in heat-exposed rats having impaired thermoregulation (Giacchino et al, 1983; Green et al, 2004; Saadat et al, 2005). The fact that there is a greater 5-HT efflux in the NAc at high ambient temperature is therefore of interest, not necessarily because this region is responsible for the heat loss mechanism per se, but rather as a reflection that such a change does occur in specific brain regions and could be involved in initiating heat loss mechanisms.

It seems clear that the enhanced locomotor activity following MDMA is not the cause of the hyperthermic response since MDMA produced a significant increase in locomotor activity in rats housed at $20^{\circ} \mathrm{C}$ but rectal temperature did not increase. Furthermore, the absolute locomotor response was no greater following MDMA in rats housed at $30^{\circ} \mathrm{C}$ than those housed at $20^{\circ} \mathrm{C}$. However, the former group also experienced a marked hyperthermic response. All these data argue against a relationship 
between locomotor activity and MDMA-induced hyperthermia, a conclusion also made by Dafters (1995) following his studies on hyperkinesis and hyperthermia following MDMA administration.

Locomotor activity following administration of amphetamines is generally considered to result from increased dopaminergic activity in the mesolimbic region, while stereotypy is associated with dopamine release in the striatum (Kelly et al, 1975; Fibiger and Phillips, 1974), and therefore the greater increase in extracellular dopamine in the NAc may account for the greater increase in locomotor activity, above control values, in animals housed at high ambient room temperature.

What is particularly interesting with regard to the enhanced dopamine release in the NAc in rats housed at high room temperature is its possible relationship to the rewarding action of MDMA. The mesolimbic dopamine system has long been suggested to be involved in the rewarding properties of recreational drugs (Fibiger and Phillips, 1974; Wise and Bozarth, 1982), including MDMA (Beardsley et al, 1986). Low-dose MDMA has been shown to have rewarding properties when given at standard room temperature as it induces a positive effect in the CPP test (Marona-Lewicka et al, 1996). Recently, Cornish et al (2003) reported greater MDMA-induced social interaction behavior in rats housed at $30^{\circ} \mathrm{C}$ compared with $20^{\circ} \mathrm{C}$ and also greater self-administration of MDMA at high temperature. It is tempting to suggest that the enhanced mesolimbic dopamine release seen at high temperature is responsible for the behavioral changes seen by Cornish et al (2003).

In addition, evidence suggests that the 5 -HT system may also be involved in mediating the rewarding and stimulant properties of MDMA either by direct or indirect mechanisms. Dopamine release in the ventral tegmental area may be facilitated by 5 -HT, possibly acting indirectly through a GABAergic mechanism (Kalivas, 1993; Prisco et al, 1994; Trifunovic and Brodie, 1996). Furthermore, various 5-HT receptor subtypes have been shown to modulate dopamine release in the NAc and the striatum (Benloucif and Galloway, 1991; Chen et al, 1991; Benloucif et al, 1993; Parsons and Justice, 1993; Lucas et al, 1997). Moreover, it appears that 5-HT release and subsequent $5-\mathrm{HT}_{1 \mathrm{~B}}$ receptor (and possibly $5-\mathrm{HT}_{2 \mathrm{~A}}$ receptor) stimulation is required for MDMA-induced hyperlocomotion to develop (Callaway et al, 1990; Kehne et al, 1996; McCreary et al, 1999). In particular, since dopamine release in the NAc is positively controlled by $5-\mathrm{HT}_{1 \mathrm{~B}}$ (Boulenguez et al, 1996) and 5- $\mathrm{HT}_{2 \mathrm{~A}}$ receptors (De Deurwaerdere and Spampinato, 1999), it may be that the increase in locomotor activity induced by MDMA is a consequence of an increase in dopaminergic transmission mediated by 5-HT in the NAc (McCreary et al, 1999).

Therefore, the facilitatory effect of MDMA on dopamine and 5-HT efflux in the NAc suggests that the rewarding properties of MDMA could be more pronounced at high ambient temperature.

Human recreational users of MDMA may experience greater psychoactive effects of MDMA when taking it in warm crowded conditions. The corollary of this, however, is that high ambient temperature produces a greater hyperthermic response to the same MDMA dose, which is associated with greater long-term neurotoxicity in rat models (Broening et al, 1995; Malberg and Seiden, 1998; O'Shea et al, 1998; Sanchez et al, 2004). This may suggest that human recreational users put themselves at greater risk by ingesting the drug in hot room conditions.

\section{ACKNOWLEDGEMENTS}

MIC thanks Ministerio de Ciencia y Tecnologia (Grant SAF2001-1437), Ministerio de Sanidad (Grant FIS02/1885, Grant G03/005), Plan Nacional sobre Drogas (Ministerio del Interior), and Fundacion Mapfre Medicina for financial support. VS thanks FIS for a studentship.

\section{REFERENCES}

Baldwin HA, Williams JL, Snares M, Ferreira T, Cross AJ, Green AR (1994). Attenuation by chlormethiazole administration of the rise in extracellular amino acids following focal ischaemia in the cerebral cortex of the rat. Br J Pharmacol 112: 188-194.

Beardsley PM, Balster RL, Harris LS (1986). Self-administration of methylenedioxymethamphetamine (MDMA) by rhesus monkeys. Drug Alcohol Depend 18: 149-157.

Benloucif S, Galloway MP (1991). Facilitation of dopamine release in vivo by serotonin agonists: studies with microdialysis. Eur J Pharmacol 200: 1-8.

Benloucif S, Keegan MJ, Galloway MP (1993). Serotonin-facilitated dopamine release in vivo: pharmacological characterization. J Pharmacol Exp Ther 265: 373-377.

Bilsky EJ, Hubbell CL, Delconte JD, Reid LD (1991). MDMA produces a conditioned place preference and elicits ejaculation in male rats: a modulatory role for the endogenous opioids. Pharmacol Biochem Behav 40: 443-447.

Bilsky EJ, Reid LD (1991). MDL72222, a serotonin 5-HT3 receptor antagonist, blocks MDMA's ability to establish a conditioned place preference. Pharmacol Biochem Behav 39: 509-512.

Boulenguez P, Rawlins JN, Chauveau J, Joseph MH, Mitchell SN, Gray JA (1996). Modulation of dopamine release in the nucleus accumbens by 5-HT1B agonists: involvement of the hippocampo-accumbens pathway. Neuropharmacology 35: 1521-1529.

Broening HW, Bowyer JF, Slikker Jr W (1995). Age-dependent sensitivity of rats to the long term effects of the serotonergic neurotoxicant $( \pm)$-3,4-methylenedioxymethampheramine (MDMA) correlates with the magnitude of the MDMA-induced thermal response. J Pharmacol Exp Ther 275: 325-333.

Brown C, Osterloh J (1987). Multiple severe complications from recreational ingestion of MDMA ('Ecstasy'). J Am Med Assoc 258: 780-781.

Callaway CW, Wing LL, Geyer MA (1990). Serotonin release contributes to the locomotor stimulant effects of 3,4-methylenedioxymethamphetamine in rats. J Pharmacol Exp Ther 254: 456-464.

Chen JP, van Praag HM, Gardner EL (1991). Activation of 5-HT3 receptor by 1-phenylbiguanide increases dopamine release in the rat nucleus accumbens. Brain Res 543: 354-357.

Colado MI, O'Shea E, Granados R, Esteban B, Martín AB, Green AR (1999). Studies on the role of dopamine in the degeneration of 5-HT nerve endings in the brain of Dark Agouti rats following 3,4-methylenedioxymethamphetamine (MDMA or 'ecstasy') administration. Br J Pharmacol 126: 911-924.

Cornish JL, Shahnawaz Z, Thompson MR, Wong S, Morley KC, Hunt GE et al (2003). Heat increases 3,4-methylenedioxymethamphetamine self-administration and social effects in rats. Eur J Pharmacol 482: 339-341.

Crespi D, Mennini T, Gobbi M (1997). Carrier-dependent and $\mathrm{Ca}(2+)$-dependent 5 -HT and dopamine release induced by (+)-amphetamine, 3,4-methylendioxymethamphetamine, 
p-chloroamphetamine and (+)-fenfluramine. $\mathrm{Br}$ J Pharmacol 121: 1735-1743.

Dafters RI (1995). Effect of ambient temperature on hyperthermia and hyperkinesis induced by 3,4-methylenedioxymethamphetamine (MDMA or 'ecstasy') in rats. Psychopharmacology 114: 505-518.

Daniela E, Brennan K, Gittings D, Hely L, Schenk S (2004). Effect of SCH 23390 on ( \pm )-3,4-methylenedioxymethamphetamine hyperactivity and self-administration in rats. Pharmacol Biochem Behav 77: 745-750.

De Deurwaerdere P, Spampinato U (1999). Role of serotonin(2A) and serotonin $(2 \mathrm{~B} / 2 \mathrm{C})$ receptor subtypes in the control of accumbal and striatal dopamine release elicited in vivo by dorsal raphe nucleus electrical stimulation. J Neurochem 73: 1033-1042.

Deutch AY, Cameron DS (1992). Pharmacological characterization of dopamine systems in the nucleus accumbens core and shell. Neuroscience 46: 49-56.

Dewar KM, Reader TA, Grondin L, Descarries L (1991). $\left[{ }^{3} \mathrm{H}\right]$ paroxetine binding and serotonin content of rat and rabbit cortical areas, hippocampus, neostriatum, ventral mesencephalic tegmentum, and midbrain raphe nuclei region. Synapse 9: 14-26.

Esteban B, O'Shea E, Camarero J, Sanchez V, Green AR, Colado MI (2001). 3,4-Methylenedioxymethamphetamine induces monoamine release, but not toxicity, when administered centrally at a concentration occurring following a peripherally injected neurotoxic dose. Psychopharmacology 154: 251-260.

Fibiger HC, Phillips AG (1974). Role of dopamine and norepinephrine in the chemistry of reward. J Psychiatr Res 11: 135-143.

Giacchino JL, Schertel ER, Horowitz JM, Horwitz BA (1983). Effect of $p$-chlorophenylalanine on thermoregulation in unrestrained rats. Am J Physiol 244: R299-R302.

Gold LH, Geyer MA, Koob GF (1989a). Neurochemical mechanisms involved in behavioral effects of amphetamines and related designer drugs. NIDA Res Monogr 94: 101-126.

Gold LH, Hubner CB, Koob GF (1989b). A role for the mesolimbic dopamine system in the psychostimulant actions of MDMA. Psychopharmacology 99: 40-47.

Gold LH, Koob GF (1988). Methysergide potentiates the hyperactivity produced by MDMA in rats. Pharmacol Biochem Behav 29: 645-648.

Green AR, Sanchez V, O'Shea E, Saadat KS, Elliott JM, Colado MI (2004). Effect of ambient temperature and a prior neurotoxic dose of 3,4-methylenedioxymethamphetamine (MDMA) on the hyperthermic response of rats to a single or repeated ('binge' ingestion) low dose of MDMA. Psychopharmacology 173: 264-269.

Henry JA (1992). Ecstasy and the dance of death. BMJ 305: 5-6.

Henry JA, Jeffreys KJ, Dawling S (1992). Toxicity and deaths from 3,4-methylenedioxymethamphetamine ('ecstasy'). Lancet 340: 384-387.

Hubner CB, Bird M, Rassnick S, Kornetsky C (1988). The threshold lowering effects of MDMA (ecstasy) on brain-stimulation reward. Psychopharmacology 95: 49-51.

Kalivas PW (1993). Neurotransmitter regulation of dopamine neurons in the ventral tegmental area. Brain Res Brain Res Rev 18: $75-113$

Kankaanpaa A, Meririnne E, Lillsunde P, Seppala T (1998). The acute effects of amphetamine derivatives on extracellular serotonin and dopamine levels in rat nucleus accumbens. Pharmacol Biochem Behav 59: 1003-1009.

Kehne JH, Ketteler HJ, McCloskey TC, Sullivan CK, Dudley MW, Schmidt CJ (1996). Effects of the selective 5-HT2A receptor antagonist MDL 100,907 on MDMA-induced locomotor stimulation in rats. Neuropsychopharmacology 15: 116-124.

Kelly PH, Seviour PW, Iversen SD (1975). Amphetamine and apomorphine responses in the rat following 6-OHDA lesions of the nucleus accumbens septi and corpus striatum. Brain Res 94: 507-522.

König JFR, Klippel RA (1963). The Rat Brain. A Stereotaxic Atlas of the Forebrain and Lower Parts of the Brain Stem. Robert $\mathrm{E}$ Krieger Publishing Co Inc.: New York.

Lamb RJ, Griffiths RR (1987). Self-injection of d,1-3,4-methylenedioxymethamphetamine (MDMA) in the baboon. Psychopharmacology 91: 268-272.

Lucas JJ, Segu L, Hen R (1997). 5-Hydroxytryptamine1B receptors modulate the effect of cocaine on c-fos expression: converging evidence using 5-hydroxytryptamine1B knockout mice and the 5-hydroxytryptamine1B/1D antagonist GR127935. Mol Pharmacol 51: 755-763.

Malberg JE, Seiden LS (1998). Small changes in ambient temperature cause large changes in 3,4-methylenedioxymethamphetamine (MDMA)-induced serotonin neurotoxicity and core body temperature in the rat. J Neurosci 18: 5086-5094.

Marona-Lewicka D, Rhee GS, Sprague JE, Nichols DE (1996) Reinforcing effects of certain serotonin-releasing amphetamine derivatives. Pharmacol Biochem Behav 53: 99-105.

McCreary AC, Bankson MG, Cunningham KA (1999). Pharmacological studies of the acute and chronic effects of (+)-3, 4methylenedioxymethamphetamine on locomotor activity: role of 5-hydroxytryptamine(1A) and 5-hydroxytryptamine(1B/1D) receptors. J Pharmacol Exp Ther 290: 965-973.

Mechan AO, Esteban B, O'Shea E, Elliott JM, Colado MI, Green AR (2002). The pharmacology of the acute hyperthermic response that follows administration of 3,4-methylenedioxymethamphetamine (MDMA, 'ecstasy') to rats. Br J Pharmacol 135: 170-180.

Mennicken F, Savasta M, Peretti-Renucci R, Feuerstein C (1992). Autoradiographic localization of dopamine uptake sites in the rat brain with ${ }^{3}$ H-GBR 12935. J Neural Transm Gen Sect 87: 1-14.

O'Shea E, Granados R, Esteban B, Colado MI, Green AR (1998). The relationship between the degree of neurodegeneration of rat brain 5-HT nerve terminals and the dose and frequency of administration of MDMA ('ecstasy'). Neuropharmacology 37: 919-926.

Parsons LH, Justice Jr JB (1993). Perfusate serotonin increases extracellular dopamine in the nucleus accumbens as measured by in vivo microdialysis. Brain Res 606: 195-199.

Prisco S, Pagannone S, Esposito E. (1994). Serotonin-dopamine interaction in the rat ventral tegmental area: an electrophysiological study in vivo. J Pharmacol Exp Ther 271: 83-90.

Rudnick G, Wall SC (1992). The molecular mechanism of 'ecstasy' [3,4-methylenedioxymethamphetamine (MDMA)]: serotonin transporters are targets for MDMA-induced serotonin release. Proc Natl Acad Sci 89: 1817-1821.

Saadat KS, O'Shea E, Colado MI, Elliott JM, Green AR (2005). The role of 5-HT in the impairment of thermoregulation observed in rats administered MDMA ('ecstasy') when housed at high temperature. Psychopharmacology (in press).

Sanchez V, Camarero J, Esteban B, Peter MJ, Green AR, Colado MI (2001). The mechanisms involved in the long-lasting neuroprotective effect of fluoxetine against MDMA ('ecstasy')-induced degeneration of 5-HT nerve endings in rat brain. Br J Pharmacol 134: $46-57$

Sanchez V, O'Shea E, Saadat KS, Elliott JM, Colado MI, Green AR (2004). Effect of repeated ('binge') dosing of MDMA to rats housed at normal and high temperature on neurotoxic damage to cerebral 5-HT and dopamine neurones. J Psychopharmacol 18: 412-416.

Schechter MD (1991). Effect of MDMA neurotoxicity upon its conditioned place preference and discrimination. Pharmacol Biochem Behav 38: 539-544.

Schenk S, Gittings D, Johnstone M, Daniela E (2003). Development, maintenance and temporal pattern of self-administration maintained by ecstasy (MDMA) in rats. Psychopharmacology 169: $21-27$. 
Screaton GR, Singer M, Cairns HS, Thrasher A, Sarner M, Cohen SL (1992). Hyperpyrexia and rhabdomyolysis after MDMA ('ecstasy') abuse. Lancet 339: 677-678.

Swerdlow NR, Koob GF (1985). Separate neural substrates of the locomotor activating-properties of amphetamine, heroin, caffeine and corticotrophin releasing factor (CRF) in the rat. Pharmacol Biochem Behav 23: 303-307.

Trifunovic RD, Brodie MS (1996). The effects of clomipramine on the excitatory action of ethanol on dopaminergic neurons of the ventral tegmental area in vitro. J Pharmacol Exp Ther 276: 34-40.

Vaccarino FJ, Amalric M, Swerdlow NR, Koob GF (1986). Blockade of amphetamine but not opiate-induced locomotion following
E O'Shea et al

antagonism of dopamine function in the rat. Pharmacol Biochem Behav 24: 61-65.

White SR, Duffy P, Kalivas PW (1994). Methylenedioxymethamphetamine depresses glutamate-evoked neuronal firing and increases extracellular levels of dopamine and serotonin in the nucleus accumbens in vivo. Neuroscience 62: 41-50.

Wise RA, Bozarth MA (1982). Action of drugs of abuse on brain reward systems: an update with specific attention to opiates. Pharmacol Biochem Behav 17: 239-243.

Yamamoto BK, Spanos LJ (1988). The acute effects of methylenedioxymethamphetamine on dopamine release in the awakebehaving rat. Eur J Pharmacol 148: 195-203. 